\title{
Penegakan Hukum Pidana Terhadap Pelaku Penambangan Minyak Tanpa Kontrak Kerja Sama
}

\author{
Moch. Reza Restu Prihatmaja, Hafrida, Tri Imam Munandar \\ Fakultas Hukum, Universitas Jambi \\ Author’s Email Correspondence: rezasamsungjambi@gmail.com
}

\begin{abstract}
ABSTRAK
Penelitian ini bertujuan 1) Untuk mengetahui dan menganalisis bagaimana penegakan Hukum Pidana terhadap pelaku IIlegal Drilling di Wilayah Hukum Pengadilan Negeri Muara Bulian; 2) Untuk mengetahui dan menganalisis apa saja kendala yang ditemukan penegakan Hukum Pidana Illegal Drilling di Wilayah Hukum Pengadilan Negeri Muara Bulian. Metode yang digunakan adalah tipe penelitian yuridis empiris. Hasil penelitian menunjukkan bahwa 1) Dalam penegakan hukum pidana terhadap pelaku illegal drilling di wilayah hukum Pengadilan Negeri Muara Bulian masih terdapat kendala dan tidak dapat berjalan dengan sempurna karena masih terdapat kelemahan dalam faktor-faktor yang mempengaruhi penegakan hukum; 2) Kendala-kendala dalam tindak pidana penambangan minyak ilegal (illegal drilling) di Kabupaten Batanghari, hal ini disebabkan oleh kurangnya kesadaran hukum warga masyarakat, terhadap perbuatan penambangan minyak ilegal (illegal drilling), sulitnya untuk membuktikan tindak pidana karena kurang barang bukti atau tidak ada barang bukti dan jumlah aparat penyidik tidak sesuai dengan jumlah kasus yang terjadi serta dikarenakan luasnya wilayah hukum Kabupaten Batanghari yang menjadikan sulitnya menegakkan hukum di wilayah hukum tersebut.
\end{abstract}

\section{ARTICLE HISTORY}

Submission: 2021-04-20

Accepted: 2021-04-25

Publish: 2021-04-26

\section{KEYWORDS:}

Criminal Law; enforcement; illegal drilling perpetrator.
Kata Kunci: Illegal Drilling; pelaku; penegakan hukum pidana.

\begin{abstract}
This study aims 1) To find out and analyze how the criminal law enforcement against illegal drilling actors in the legal area of the Muara Bulian District Court; 2) To find out and analyze what are the obstacles found by enforcement of the Illegal Drilling Criminal Law in the Legal Area of the Muara Bulian District Court. The method used is the empirical juridical research type. The results showed that 1) In enforcing criminal law against perpetrators of illegal drilling in the jurisdiction of the Muara Bulian District Court, there are still obstacles and cannot run properly because there are still weaknesses in the factors that affect law enforcement; 2) Constraints in the criminal act of illegal oil mining (illegal drilling) in Batanghari Regency, this is due to the lack of legal awareness of the community, regarding illegal oil mining activities (illegal drilling), the difficulty of proving criminal acts due to lack of evidence or not. There is evidence and the number of investigating officers does not match the number of cases that have occurred and due to the vast jurisdiction of Batanghari Regency which makes it difficult to enforce the law in that jurisdiction.
\end{abstract}




\section{A. PENDAHULUAN}

Salah satu permasalahan yang timbul dari adanya pembangunan yaitu mengenai tindak Ekplorasi atau ekploitasi minyak dan gas bumi tanpa mempunyai kontrak kerja atau tanpa izin usaha pengelolaan minyak dan gas bumi. Undang-Undang Nomor 22 Tahun 2001 tentang Minyak dan Gas Bumi telah mengatur tentang kegiatan usaha yang berkaitan dengan minyak dan gas bumi, baik kegiatan usaha Hulu maupun Kegiatan usaha hilir.

Negara wajib melakukan pengaturan agar pemanfaatan sumber daya alam sebesar-besarnya untuk kemakmuran rakyat. Berbagai peraturan perundangundangan telah dibentuk oleh Pemerintah sebagai personifikasi negara yaitu:

a. Undang-Undang Dasar Negara Republik Indonesia Tahun 1945;

b. Konvenan Hak Ekonomi, Sosial dan Budaya diratifikasi oleh Indonesia melalui Undang-Undang Nomor 11 Tahun 2005;

c. Kovenan Hak Sipil dan Politik diratifikasi oleh Indonesia melalui Undang Undang Nomor 12 Tahun 2005;

d. Undang-Undang Nomor 5 Tahun 1960 tentang Ketentuan Pokok Pokok Agraria;

e. Undang-Undang Nomor 5 Tahun 1990 tentang konservasi Sumber Daya Alam Hayati dan Ekosistemnya;

f. Undang-Undang Nomor 41 Tahun 1999 tentang Kehutanan;

g. Undang-Undang Nomor 39 tahun 1999 tentang HAM;

h. Undang-Undang Nomor 7 Tahun 2004 tentang Sumber Daya Air;

i. Undang-Undang Nomor 25 Tahun 2007 tentang Penanaman Modal;

j. Undang-Undang Nomor 27 Tahun 2007 tentang Pengelolaan Wilayah Pesisir dan Pulau-Pulau Kecil.

Dalam Undang-Undang Nomor 22 Tahun 2001 tentang Minyak dan Gas Bumi tidak dikenal dengan nomenklatur eksploitasi minyak dan gas bumi yang dilakukan oleh rakyat. Justru sebaliknya, dalam undang-undang tersebut mengatur sanksi pidana bagi setiap orang yang melakukan kegiatan usaha hulu tanpa izin.

Langkah melegalitaskan kegiatan eksploitasi minyak dan gas bumi yang dilakukan oleh rakyat memiliki dua sisi yang berseberangan. Di sisi yang bermanfaat yaitu, kegiatan eksploitasi minyak dan gas bumi yang dilakukan oleh rakyat memiliki aspek peningkatan perekonomian masyarakat di sekitar lokasi kegiatan eksploitasi minyak dan gas bumi yang dilakukan oleh rakyat tersebut. Adi Candra mengemukakan:

"Hasil penelitian diketahui bahwa rata-rata tingkat pendapatan masyarakat penambang sebesar Rp.17.172.834,00 perbulan, pendapatan bagian pengolahan hasil penambangan seperti buruh angkut dan penyuling minyak sebesar Rp.3.407.176,00 perbulan, dan tingkat pendapatan masyarakat sekitar sebesar Rp.1.756.816,00. Perbandingan pendapatan masyarakat pengelola sumur minyak tua dengan pendapatan masyarakat sekitar serta dengan ukuran kemiskinan memperlihatkan bahwa pendapatan masyarakat sehingga rata-rata pen- dapatan berada diatas garis kemiskinan. Dengan garis kemiskinan Internasional berdasar- kan ukuran Bank Dunia 1 dolar (Rp.279.960,00) perjiwa perbulan terdapat $18,39 \%$ rumah tangga responden berada dibawah garis kemiskinan. Tingkat kemiskinan rumah tangga responden relatif lebih 
kecil jika menggunakan garis kemiskinan BPS untuk nasional, yaitu sebanyak $3,45 \%$ rumah tangga responden." 1

Tetapi hal ini tidak selalu mendatangkan manfaat atau kelebihan seringkali mendatangkan kerugian atau hal yang negatif, Di satu sisi yang merugikan yaitu eksploitasi minyak dan gas bumi yang dilakukan oleh rakyat sebagai industri yang mempunyai resiko lingkungan yang tinggi selalu mendapatkan perhatian khusus oleh publik. Pengelolaan pertambangan selama ini tampaknya lebih mengutamakan keuntungan secara ekonomi sebesar-besarnya, yang dilain pihak kurang memperhatikan aspek sosial dan lingkungan hidup. Kegiatan yang bersifat eksploitasi tersebut memberi dampak terhadap lingkungan hidup. Karena masalah lingkungan hidup pada dasarnya menurut Siswanto Sunarso timbul akibat:

1. Dinamika pertumbuhan pendudukan yang cepat, persebaran tidak proprsional, tidak adanya keseimbangan struktur penduduk.

2. Pemanfaatan dan pengelolaan sumber daya yang kurang bijaksana. Karena dikejar mencapai target keuntungan sebanyak-banyaknya, berbagai sumber alam dikuras habis-habisan tanpa mempertimbangkan generasi mendatang.

3. Kurang terkendalinya pemanfaatan ilmu pengetahuan dan teknologi maju. Saat ini teknologi untuk menyedot minyak dari perut bumi dengan teknologi canggih. Sehingga manusia berlomba menyedot minyak dalam jutaan barel per hari. Demikian pula teknologi untuk penebangan hutan.

4. Dampak negatif yang sering timbul dari kemajuan ekonomi yang seharusnya positif. Timbulnya industri-industri raksasa, tidak jarang menimbulkan kerusakan dan sungai maupun di muara sungai. Ini berarti menumbuh mata pencaharian nelayan. Tidak jarang menimbulkan urbanisasi dan kejahatan-kejahatan di kota, karena sulitnya mencari pekerjaan.

5. Benturan tata ruang. Kawasan seharusnya untuk reboisasi dijadikan kawasan industri. Kawasan seharusnya untuk taman nasional (monas) dulu digunakan untuk Jakarta Fair dan tempat hiburan dengan penuh bangunan. ${ }^{2}$

Undang-Undang Nomor 22 Tahun 2001 tentang Minyak dan Gas Bumi tidak dikenal dengan nomenklatur eksploitasi minyak dan gas bumi yang dilakukan oleh rakyat. Justru sebaliknya, dalam undang-undang tersebut mengatur sanksi pidana bagi setiap orang yang melakukan kegiatan usaha hulu tanpa izin.

Pasal 52 Undang-Undang Nomor 22 Tahun 2001 tentang Minyak dan Gas Bumi menentukan: "setiap orang yang melakukan eksplorasi dan atau eksploitasi tanpa mempunyai kontrak kerja sama dipidana dengan pidana penjara paling lama enam tahun dan denda paling tinggi Rp 60 miliar". Hal ini diperkuat oleh Pasal 57 ayat (2) yang menyatakan bahwa tindak pidana sebagaimana dimaksud Pasal 52, Pasal 53, Pasal 54, dan Pasal 55 adalah kejahatan.

Namun, terlepas dari masih lemahnya hukum pidana materiil untuk melegalitaskan kegiatan penambangan minyak bumi, upaya tersebut harus dilakukan

1 Adi Candra, "Pemanfaatan Sumur Minyak Tua Sisa Eksploitasi Peninggalan Belanda Dalam Hubungannya Dengan Perekonomian Masyarakat Di Kabupaten Musi Banyuasin", Jurnal Muamalah, Vol . 3, No. 1, 2017, hlm. 60. http://jurnal.radenfatah.ac.id

2 Siswanto Sunarso, Hukum Pidana Lingkungan Hidup dan Strategi Penyelesaian Sengketa, Rineka Cipta, Jakarta, 2005, hlm. 5. 
dengan mengedepankan due process of law (proses hukum yang adil), bukan dengan arbitrary process (melalui kesewenang-wewenangan aparat penegak hukum). Jangan sampai penegakan hukum dilakukan dengan melanggar hukum itu sendiri. Sehingga diperlukan penegakan hukum pidana untuk mengatasi persoalan tersebut.

Adapun yang dimaksud dengan penegakan hukum menurut pendapat Jimly Asshiddiqie yang mengatakan:

"Penegakan hukum adalah proses dilakukannya upaya untuk tegaknya atau berfungsinya norma-norma hukum secara nyata sebagai pedoman perilaku atau hubungan-hubungan hukum dalam kehidupan bermasyarakat dan bernegara. Dalam pengertian lain penegakan hukum merupakan upaya yang dilakukan untuk menjadikan hukum, baik dalam arti formil yang sempit maupun dalam arti materil yang luas, sebagai pedoman perilaku dalam setiap perbuatan hukum, baik oleh para subjek hukum yang bersangkutan maupun oleh aparatur penegak hukum yang resmi diberi tugas dan kewenangan oleh undang-undang untuk menjamin berfungsinya norma-norma hukum yang berlaku dalam kehidupan bermasyarakat dan bernegara."3

Keberhasilan hukum ketika ditegakkan dalam kehidupan masyarakat juga terkait dengan faktor-faktor yang mempengaruhinya. Dalam hal ini menurut Soerjono Soekanto yang mengatakan:

"Bahwa masalah pokok penegakan hukum sebenarnya terletak pada faktorfaktor yang mungkin mempengaruhinya. Faktor-faktor tersebut mempunyai arti yang netral, sehingga dampak positif atau negatifnya terletak pada isi faktor-faktor tersebut. Faktor-faktor tersebut adalah sebagai berikut:

1. Faktor hukumnya sendiri, yang didalam hal ini mengenai Undang-Undang saja.

2. Faktor penegak hukum, yakni pihak-pihak yang membentuk maupun menerapkan hukum.

3. Faktor sarana atau fasilitas yang mendukung penegakan hukum.

4. Faktor masyarakat, yakni lingkungan dimana hukum tersebut berlaku atau diterapkan.

5. Faktor kebudayaan, yakni sebagai hasil karya, cipta dan rasa yang didasarkan pada karsa manusia di dalam pergaulan hidup.

Kelima faktor tersebut saling berkaitan antara yang satu dengan yang lainnya karena semuanya merupakan esensi dari penegakan hukum serta juga merupakan tolak ukur dari pada afektivitas dari penegakan hukum. ${ }^{4}$

Kenyataan yang terjadi di lapangan menunjukkan bahwa di Kabupaten Batanghari ternyata penambangan minyak ilegal (illegal drilling). Penambangan minyak ilegal (illegal drilling) ini menimbulkan masalah yang tidak kecil bagi Pemerintah Daerah Kabupaten Batanghari. Hal ini dikarenakan minyak ilegal (illegal drilling) ini dilakukan oleh masyarakat dengan teknologi yang tidak ramah dengan lingkungan yaitu menggunakan mesin sedot atau mesin semprot dan menggunakan zat kimia yang limbahnya langsung dibuang ke sungai sehingga dapat menimbulkan bencana baik sekarang maupun bagi anak cucu dimasa yang akan datang.

3 Jimly Ashidiqie, Penegakan Hukum, http://solusihukum.com/artikel/artikel 49.php.10, 2019.

Soerjono Soekanto, Faktor-Faktor Yang Mempengaruhi Penegakan Hukum, Raja Grafindo Persada, Jakarta, 1983, hlm. 8. 
Kegiatan pertambangan minyak ilegal (illegal drilling) yang terdapat di Kabupaten Batanghari, tidak satupun yang memilliki izin, mereka melakukan pertambangan minyak ilegal (illegal drilling)5. Modus illegal drilling merupakan tindak pidana pencurian minyak.

"Pencurian minyak terjadi hampir setiap hari dalam tiga modus yaitu illegal tapping, illegal drilling dan penyelewengan BBM bersubsidi. (1) Modus illegal tapping adalah pencurian minyak dengan cara melubangi pipa penyaluran minyak milik perusahaan. Selanjutnya minyak tersebut ditampung dalam tempat tertentu seperti mobil tangki, kolam penampungan hingga sumur minyak. (2) Modus illegal drilling merupakan penambangan ilegal dengan mengolah minyak dari sumur minyak tua atau membuat sumur tanpa izin."6

Aktivitas minyak ilegal (illegal drilling) tidak terlepas dari adanya permasalahan sosial dan ekonomi saat ini. Krisis ekonomi yang berkepanjangan mengakibatkan terbatasnya lapangan kerja sehingga masyarakat tingkat bawah cenderung mencari peluang untuk mendapatkan pendapatan (income) yang cepat tanpa mengindahkan sebesar apapun resiko dan dampak yang diakibatkannya dengan hanya sekedar mempertahankan hidupnya.

Ditinjau dari sudut kaidah atau peristiwa hukum (dassollen), perumusan ketentuan pidana penambangan minyak ilegal (illegal drilling) di dalam Undangundang minyak dan gas bumi, terdapat komitmen yang kuat dari Negara untuk mencegah dan atau memberantas tindak pidana penambangan minyak ilegal (illegal drilling). Sehingga kelestarian lingkungan hidup tetap terjaga.

Permasalahannya bagaimanakah pelaksanaan penanggulangan tindak pidana penambangan minyak ilegal (illegal drilling) yang dilakukan oleh penegak hukum dalam menerapkan ketentuan normatif tersebut apakah telah benar-benar mampu diwujudkan oleh penegak hukum di lapangan, menjadi peristiwa hukum konkrit (dassein), berupa penegakan hukum yang tegas terhadap pelaku tindak pidana penambangan minyak ilegal (illegal drilling), sehingga tidak terjadi lagi tindak penambangan minyak ilegal (illegal drilling) atau setidaknya dapat ditekan intensitasnya.

Data Dinas Lingkungan Hidup Kabupaten Batanghari memaparkan luas wilayah yang telah dirusak akibat penambangan minyak ilegal (illegal drilling) di Kab. Batanghari yaitu seluas 225 ha (dua ratus dua puluh lima). Yang diduga dilakukan oleh lebih kurang 450 (empat ratus lima puluh) unit mesin yang beroperasi.

Dalam tiga tahun terakhir di wilayah hukum Polres Batanghari, tindak pidana penambangan minyak ilegal (illegal drilling) selalu saja terjadi sebagaimana terlihat pada tabel di bawah ini.

5 Ibid.

6 Riyandani Rahmadiah Lioty, Penanganan Illegal Tapping, Illegal Drilling dan Penyelewengan Bahan Bakar Minyak (BBM) Bersubsidi di Indonesia Tahun 2011-2015, Journal of International Relations, Vol. 3, No. 4, 2017, hlm. 96. http://ejournal-s1.undip.ac.id/index.php/jihi

https://mediarealitas.com/, diakses 04 Desember 2019. 
Tabel 1

Jumlah Kasus penambangan minyak ilegal di Kabupaten Batanghari Tahun 2016-2018

\begin{tabular}{|c|c|c|c|c|c|}
\hline No. & Tahun & $\begin{array}{c}\text { Polres } \\
\text { Batanghari }\end{array}$ & $\begin{array}{c}\text { Kejaksaan } \\
\text { Negeri Muara } \\
\text { Bulian }\end{array}$ & $\begin{array}{c}\text { Pengadilan } \\
\text { Negeri Muara } \\
\text { Bulian }\end{array}$ & $\begin{array}{c}\text { Jeratan } \\
\text { Pasal } \\
\text { Pidana }\end{array}$ \\
\hline 1 & 2016 & 3 & 2 & 2 & $\begin{array}{c}\text { Pasal } 52 \\
\text { UU Migas }\end{array}$ \\
\hline 2 & 2017 & 6 & 3 & 3 & $\begin{array}{c}\text { Pasal } 52 \\
\text { UU Migas }\end{array}$ \\
\hline 3 & 2018 & 5 & 3 & 2 & $\begin{array}{c}\text { Pasal 52, } \\
53 \text { UU } \\
\text { Migas }\end{array}$ \\
\hline
\end{tabular}

Sumber Data: Polres Batanghari

Pada tabel tersebut di atas terlihat bahwa dalam tiga tahun belakang ini, jumlah kasus tindak pidana penambangan minyak ilegal (illegal drilling) yang masuk ke Polres Batanghari adalah sebanyak 14 (empat belas) kasus, dengan rincian 3 (tiga) kasus tahun 2016, 6 (enam) kasus tahun 2017 dan 5 (lima) kasus tahun 2018. Data yang penulis peroleh di Kepolisian Resort Batanghari tersebar di dalam beberapa daerah seperti daerah Desa Pompa Air, Desa Bungku Desa Bambu Kuning Kecamatan Bajubang dan Kecamatan Tempino Kabupaten Batanghari. dapat dilihat secara jelas penegakan hukum yang dilakukan oleh Kepolisian Resort Batanghari terhadap pelaku tindak pidana penambangan minyak ilegal (illegal drilling) di Kabupaten Batanghari mengalami kemajuan, namun belum optimal dan efektif seperti yang diharapkan.

Berdasarkan 14 (empat belas) berkas perkara yang diproses oleh pihak Kepolisian Resort Batanghari hanya orang-orang yang sedang melakukan kegiatan penambangan minyak ilegal (illegal drilling) saja, sedangkan pemilik peralatan penambangan tidak ikut dijadikan tersangka oleh pihak penyidik, begitu juga orangorang yang sering memback-up penambangan ilegal ini tidak pernah ditangkap oleh pihak kepolisian, sehingga penegakan hukum yang dilakukan oleh Kepolisian Resort Batanghari terhadap pelaku tindak pidana penambangan minyak ilegal (illegal drilling) ini terlihat belum efektif.

Terjadinya tindak pidana penambangan minyak ilegal (illegal drilling) di Kabupaten Batanghari bukanlah menandakan bahwa tidak ada suatu usaha atau upaya penanggulangan yang dilakukan guna mengatasi dan memberantas tindak pidana tersebut melainkan masih ditemui adanya suatu permasalahan atau kendala dalam pelaksanaannya. 


\section{B. METODE PENELITIAN}

Dalam artikel penelitian yang digunakan yaitu, Tipe penelitian ini adalah Yuridis Empiris, yaitu yang berkaitan dengan persoalan hukum dalam praktek di lapangan, atau dengan kata lain "Penelitian hukum empiris adalah sebuah metode penelitian hukum yang berupaya untuk melihat hukum dalam artian yang nyata atau dapat dikatakan melihat, meneliti bagaimana bekerjanya hukum di masyarakat". Artinya dalam penelitian ini dimaksudkan untuk mengetahui penegakan hukum pidana terhadap illegal drilling di wilayah hukum Pengadilan Negeri Muara Bulian. Menurut Bahder Johan Nasution, bahwa "Penelitian ilmu empiris bahwa tujuan penelitian ilmu empiris bertujuan untuk sejauhmana bekerjanya hukum ditengah masyarakat"8. Pendekatan penelitian yuridis empiris pada prinsipnya adalah penggabungan antara pendekatan yuridis normatif dengan penambahan unsur-unsur empiris.

\section{PEMBAHASAN}

\section{Tindak Pidana Illegal Drilling}

Dalam ilmu pengetahuan hukum pidana, istilah tindak pidana ini merupakan salah satu istilah dasar yang merupakan pengertian hukum, di samping pertanggung jawaban pidana. Istilah "peristiwa pidana" atau "Tindak Pidana" adalah sebagai terjemahan dari istilah bahasa Belanda "Strafbaarfeit" atau "delict". ${ }^{9}$

Selanjutnya dikemukakan oleh Van Hamel sebagaimana dikutip oleh Moeljatno, strafbaarfeit memiliki pengertian yaitu "kelakuan orang (menselijke gedraging) yang dirumuskan dalam wet, yang bersifat melawan hukum, yang patut dipidana (strafwaardig) dan dilakukan dengan kesalahan".10

Jika melihat pengertian-pengertian ini maka disitu dalam pokoknya ternyata:

1. Bahwa feit dalam strafbaarfeit berarti handeling, kelakuan atau tingkah laku;

2. Bahwa pengertian strafbaarfeit dihubungkan dengan kesalahan orang yang mengadakan kelakuan tadi.

Istilah lainnya yang populer ialah "perbuatan pidana", yakni istilah yang dirumuskan oleh Moeljatno, ia mengemukakan pendapatnya tentang istilah "perbuatan Pidana", sebagai berikut: "Perbuatan pidana adalah perbuatan yang dilarang oleh suatu aturan hukum larangan mana disertai ancaman (sanksi) yang berupa pidana tertentu, bagi barang siapa yang melanggar larangan tersebut."11 Lebih lanjut Moeljatno, mengemukakan sebagai berikut:

"Peristiwa ini saja tak mungkin dilarang. Hukum pidana tidak melarang adanya orang mati, tetapi melarang adanya orang mati karena perbuatannya orang lain. Jika matinya orang itu karena keadaan alam entah karena penyakit, entah karena sudah tua, entah karena tertimpa pohon yang roboh ditiup angin puyuh, maka peristiwa itu tidak penting sama sekali bagi hukum pidana. Juga tidak penting, jika matinya orang itu karena binatang. Baru apabila matinya ada hubungan dengan kelakuan orang lain, di situlah peristiwa tadi menjadi pening bagi hukum pidana". 12

8 Bahder Johan Nasution, Metode Penelitian Hukum, Mandar Maju, Bandung, 2008, hlm. 81.

9 C.S.T. Kansil dan Christine S.T. Kansil, Pokok-Pokok Hukum Pidana, Pradnya Paramita, Jakarta, 2007, hlm. 37.

10 Moeljatno, Asas-Asas Hukum Pidana, Bina Aksara, Jakarta, 1987, hlm. 61.

11 Moeljatno, Op. Cit., hlm. 59.

12 Ibid., hlm. 60. 
Sedangkan istilah "tindak pidana" pun tidak luput dari kritikan. Moeljatno mengemukakan, "karena tumbuhnya dari pihak kementerian Kehakiman, sering dipakai dalam perundang-undangan."13 Meskipun demikian, pemakaian istilah "tindak pidana" ini sangat meluas serta dominan sekarang ini dalam peraturan perundangundangan pada umumnya, dan perundang-undangan pada khusunya.

Negara Indonesia merupakan salah satu negara di dunia yang mempunyai banyak kekayaan alam baik yang dapat diperbaharui maupun yang tidak dapat diperbaharui. Sumber daya mineral sebagai salah satu sumber daya yang dimiliki Bangsa Indonesia, apabila dikelola dengan baik akan memberikan kontribusi terhadap pembangunan ekonomi negara. Gatot Supramono mengemukakan:

"Indonesia dikarunia sumber daya alam dan energi yang melimpah. Potensi sumber daya dan cadangan mineral metalik terbesar di 437 lokasi di Indonesia bagian barat dan timur, seperti tembaga dan emas di Papua, emas di Nusa Tenggara, nikel di Sulawesi dan kepulauan Indonesia timur, bauksit dan batu bara di Kalimantan dan mineral lainnya yang masih tersebar di berbagai tempat."14

Pengaturan atau regulasi tentang pertambangan ini disebut juga dengan istilah hukum pertambangan. Hukum pertambangan adalah keseluruhan kaidah hukum yang mengatur kewenangan negara dalam pengelolaan bahan galian (tambang) dan mengatur hubungan hukum antara negara dengan orang atau badan hukum dalam pengelolaan dan pemanfaatan bahan galian. Dalam hal ini H. Salim HS, mengartikan: "Hukum Pertambangan adalah keseluruhan kaedah hukum yang mengatur kewenangan Negara dalam pengelolaan bahan galian (tambang) dan mengatur hubungan antara Negara dengan orang dan atau badan hukum dalam pengelolaan dan pemanfaatan bahan galian (tambang)". 15

Undang-Undang Dasar Negara Republik Indonesia 1945, mengenai minyak dan gas bumi telah diatur di dalam bab XIV Pasal 33 ayat (3) yang menentukan: "Bumi, dan air dan kekayaan alam yang terkandung di dalamnya dikuasai oleh Negara dan dipergunakan untuk sebesar-besar kemakmuran rakyat.

Untuk lebih jelasnya perlu ditelaah aturan hukum terkait pengaturan atau regulasi tentang pertambangan khususnya berkenaan dengan eksploitasi minyak bumi. Hal tersebut dapat dikemukakan sebagai berikut:

1. Undang-Undang Dasar Negara Republik Indonesia Tahun 1945

Undang-Undang Dasar 1945 Pasal 33 ayat (3) telah mengamanatkan dan menyebutkan bahwa :"Bumi , air, dan kekayaan alam yang terkandung di dalamnya dikuasai oleh Negara dan digunakan sebesar-besarnya untuk kemakmuran rakyat." Artinya pengelolaan sumber daya alam atau kekayaan alam yang terkandung di dalam negara seharusnya dipergunakan sebesar-besarnya bagi kemakmuran rakyat. Kekayaan alam yang terkandung didalamnya termasuk minyak dan gas bumi yang merupakan sumber daya alam yang tak terbaharui (unrenewable resources) dan sangat langka. Minyak dan Gas Bumi sendiri mempunyai nilai yang

13 Ibid.

14 Gatot Supramono, Hukum Pertambangan Mineral dan Batu Bara di Indonesia, Rineka Cipta, Jakarta, 2012, hlm. 1.

15 Salim H.S, Hukum Pertambangan di Indonesia, PT. Raja Grafindo Persada, Jakarta, 2005, hlm. 8. 
sangat strategis bagi kepentingan hidup bangsa Indonesia sebagai sumber energi dalam negeri dan sumber penerimaan negara yang sangat signifikan

2. Undang-Undang Nomor 22 Tahun 2001 Tentang Minyak dan Gas Bumi Pengertian Minyak Bumi Menurut Undang-Undang Nomor 22 Tahun 2001 Tentang Minyak dan Gas Bumi Pasal 1 angka 1, menyebutkan bahwa: Minyak Bumi adalah hasil proses alami berupa hidrokarbon yang dalam kondisi tekanan dan temperature atmosfer berupa fasa cair atau padat, termasuk aspal, lilin mineral atau ozokerit, dan bitumen yang diperoleh dari proses penambangan, tetapi tidak termasuk batu bara atau endapan hidrokarbon lain yang berbentuk padat yang diperoleh dari kegiatan yang tidak berkaitan dengan kegiatan usaha Minyak dan Gas Bumi.

3. Pasal 52 Undang-Undang Nomor 22 Tahun 2001

...... Minyak dan Gas Bumi menentukan: "setiap orang yang melakukan eksplorasi dan atau eksploitasi tanpa mempunyai kontrak kerja sama dipidana dengan pidana penjara paling lama enam tahun dan denda paling tinggi Rp 60 miliar". Hal ini diperkuat oleh Pasal 57 ayat (2) yang menyatakan bahwa tindak pidana sebagaimana dimaksud Pasal 52, Pasal 53, Pasal 54, dan Pasal 55 adalah kejahatan.

Salah satu kegiatan usaha Migas adalah kegiatan Eksplorasi dan Eksploitasi. Eksplorasi sendiri menurut Undang-Undang Nomor 22 Tahun 2001 Tentang Minyak dan Gas Bumi Pasal 1 angka 8 menentukan bahwa: "Eksplorasi adalah kegiatan yang bertujuan memperoleh informasi mengenai kondisi geologi untuk menemukan dan memperoleh perkiraan cadangan Minyak dan Gas Bumi di wilayah kerja yang ditentukan."

Sedangkan pengertian eksploitasi menurut Undang-Undang Nomor 22 Tahun 2001 Tentang Minyak dan Gas Bumi Pasal 1 angka 9, menentukan bahwa:

Eksploitasi adalah rangkaian kegiatan yang bertujuan untuk menghasilkan Minyak dan Gas Bumi dari wilayah kerja yang ditentukan, yang terdiri atas pengeboran dan penyelesaian sumur, pembangunan sarana pengangkutan, penyimpanan, dan pengolahan untuk pemisahan dan pemurnian Minyak dan Gas Bumi di lapangan serta kegiatan lain yang mendukungnya.

Pihak-pihak yang terkait dalam kegiatan usaha Migas ini antara lain adalah Negara/Pemerintah, Perusahaan Migas beserta karyawannya, dan rakyat yang dalam kegiatan usaha Migas, seharusnya mereka mempunyai andil dan hak atas adanya kegiatan eksploitasi yang telah dilakukan di wilayahnya.

Jadi dapat disimpulkan bahwa illegal drilling adalah suatu kegiatan tindak pidana administratif yang berupa perizinan untuk melakukan kegiatan eksploitasi atau pengeboran tanpa adanya kontrak kerja sama yang mana pengaturan tersebut di sebutkan dalam Undang-Undang No 22 Tahun 2001 Pasal 52 dan 53.

\section{Penegakan Hukum Pidana Terhadap Pelaku Illegal Drilling di Wilayah Hukum Pengadilan Negeri Muara Bulian}

Undang-Undang No 22 Tahun 2001 tentang Minyak dan Gas Bumi telah dengan menjelaskan mengenai kegiatan-kegiatan yang berkaitan dengan penambangan minyak dan gas bumi yang mana pada Pasal 52 dan Pasal 53 telah menjelaskan bahwa kegiatan penambangan minyak dan gas bumi tanpa kontrak kerja sama merupakan sebuah tindak pidana yang mana tindak pidana ini termasuk kedalam tindak pidana 
administratif dikarenakan tindak pidana ini berkaitan dengan izin untuk melakukan kegiatan pengeboran tanpa adanya kontrak kerja atau izin.

Kegiatan pengeboran atau penambangan minyak secara illegal ini merupakan sebuah kegiatan yang salah dan merugikan bagi negara dan lingkungan dan merupakan sebuah tindak pidana yang merupakan sebuah delik biasa yang mana kegiatan ini harus ditindak oleh aparat penegak hukum meskipun tidak ada laporan dari masyarakat bahwa ada kegiatan pengeboran tetapi kegiatan ini tetap harus di hukum dan di berikan sanksi terhadap si pelaku yang mana ketentuan pidana ini telah diatur dalam Undang-Undang No 22 Tahun 2001 tentang Minyak dan Gas Bumi pasal 52 dan Pasal 53.

Banyaknya kasus tindak pidana illegal drilling yang terdaftar di Polres Batanghari dalam tiga tahun belakangan ini adalah sebanyak 14 (empat belas) kasus. Kuantitas tindak pidana illegal drilling ini cukup banyak terjadi dan meningkat tiap tahunnya. "Berdasarkan Data Dinas Lingkungan Hidup Kabupaten Batanghari memaparkan luas wilayah yang telah dirusak akibat penambangan minyak ilegal (illegal drilling) di Kab. Batanghari yaitu seluas 225 ha (dua ratus dua puluh lima). Yang diduga dilakukan oleh lebih kurang 450 (empat ratus lima puluh) unit mesin yang beroperasi". 16 Menurut dari Dinas Lingkungan Hidup diperoleh, jumlah sumur illegal yang di Kecamatan Bajubang dan Tempino Kabupaten Batanghari mencapai 2.300 titik lebih sumur bor yang menghasilkan paling sedikit 4.000 barel minyak hilang lewat pengeboran tersebut yang mengakibatkan kerugian negara mencapai milyaran rupiah.

Terkait dengan illegal drilling di Kabupaten Batanghari yang terus meningkat, Novaizal mengemukakan bahwa:

"Illegal drilling yang terjadi di Kabupaten Batanghari pada saat ini makin memprihatinkan ini dapat dilihat makin banyaknya masyarakat melakukan illegal drilling dan hal ini dapat menimbulkan dampak negatif bagi masyarakat sekitar maupun terhadap lingkungan. Di samping itu kegiatan illegal drilling juga bisa merusak lahan pertanian yang produktif sehingga dalam jangka waktu yang relatif panjang lahan tersebut tidak bisa lagi diolah menjadi lahan pertanian." 17

Akibat maraknya tindakan illegal drilling ini tentu saja berakibat negatif terhadap kelestarian lingkungan. Keterlibatan masyarakat dalam Illegal drilling ini perlu dipandang sebagai suatu akibat tidak diberikannya akses bagi masyarakat hukum adat yang berada disekitar lokasi. Kterlibatan masyarakat di sekitar lokasi ini menurut Helmi dkk. setidaknya diperlukan beberapa tindakan dan langkah-langkah berikut: "Pertama, memastikan bahwa anggota masyarakat adat orang-orang dan manfaatnya dari hak dan peluang yang sama sebagai anggota populasi lainnya sebagaimana diatur dalam Legislasi. Kedua, mempromosikan realisasi penuh sosial, ekonomi, hak-hak budaya masyarakat adat berdasarkan dan identitas sosial, adat istiadat dan tradisi, dan institusi. Ketiga, membantu anggota masyarakat yang bersangkutan untuk menghilangkan kesenjangan sosial ekonomi yang mungkin terjadi antara masyarakat adat dan penduduk lain yang juga tinggal di negara yang sesuai

16 Op. Cit.

17 Wawancara dengan Novaizal Varia Utama, Kepala Seksi Pengawasan Dinas Energi dan Sumber Daya Mineral (ESDM) Provinsi Jambi, Tanggal 22 Januari 2020. 
dengan dengan aspirasi dan cara hidup mereka. Keempat, pelaksanaan Konvensi ini menekankan prinsip dialog dan Musyawarah"18

Tersendatnya akses masyarakat hukum adat disekitar wilayah hutan akan mengakibatkan masyarakat sekita melakukan tindakan tindakan yang dianggap bertentangan dengan hukum. Selanjutnya konflik yang terjadi akan menimbulkan beberapa konsekwensi seperti: "Pertama, hilangnya akses masyarakat hukum adat terhadap tanah, wilayah dan sumber daya alam. Kedua kerusakan struktur sosial unit masyarakat hukum adat disebabkan oleh struktur agraria. Ketiga, terdapat kerusakan kualitas ekologis yang berkaitan langsung dengan kualitas turunan dari manusia yang hidupnya bergantung pada sumber daya agraria. Selain itu, keberadaan masyarakat hukum adat di berbagai daerah masih ada, baik yang masih menerapkan tradisi yang diwarisi dari mereka dan telah mulai mengikuti perkembangan yang berasal dari Luar"19

\section{Kendala Yang Ditemukan Dalam Penegakan Hukum Pidana Illegal Drilling di Wilayah hukum Pengadilan Negeri Muara Bulian}

Terkait dengan jumlah personil kepolisian Resort Muara Bulian pada bagian Tipiter secara kuantitatif memiliki kekurangan dan tidak seimbang dengan wilayah hukum yang harus dilakukan pengawasan. Walaupun demikian dalam pelaksanaan penegakan hukum atas pelaku tindak pidana penambangan minyak ilegal (illegal drilling) selalu berkoordinasi dengan bagian krimumum. Adapun jumlah anggota unit tindak pidana tertentu adalah berjumlah 4 (empat) orang, sebagaimana diuraikan dalam tabel berikut:

\section{Tabel}

\section{Jumlah Anggota Unit Tindak Pidana Tertentu Polres Batanghari}

No. Nama Pangkat Jabatan Pendidikan

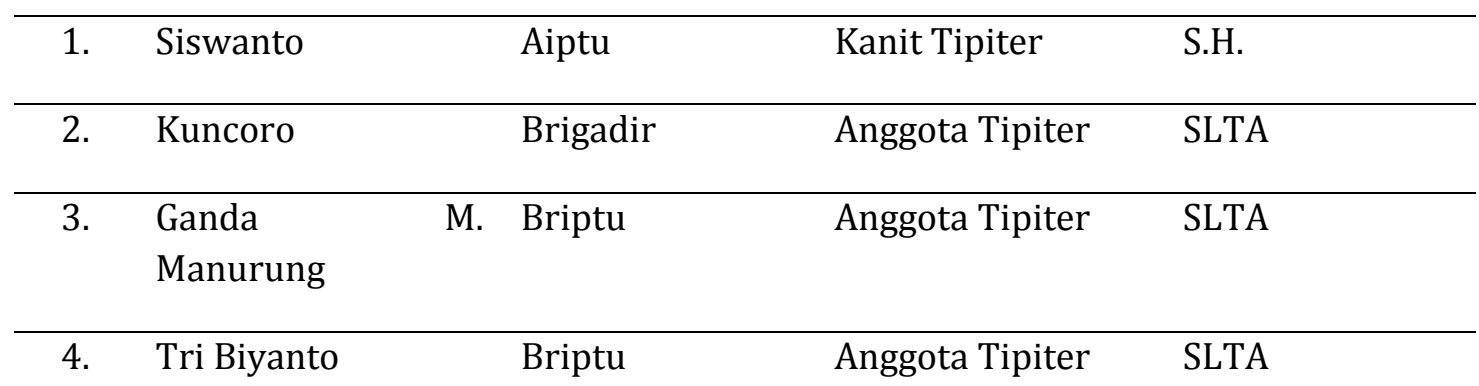

Jumlah personil unit Tipiter Kepolisian Resort Muara Muara Bulian yang hanya 4 (empat) orang, maka penegakan hukum terhadap tindak pidana penambangan

18 Helmi, Hafrida, Retno Kusniati, Fauzi Syam, Indriya Fathni, Hartati, dan Johni Najwan, "LEGAL PROTECTION TO MANAGE FOREST RESOURCES BASED ON LOCAL WISDOM.", Journal of Critical Reviews, Vol. 7, No. 9, 2020, hlm. 623. http://www.jcreview.com/?mno=112244

19 Helmi, Hafrida, Fitria, dan Johni Najwan, "Documenting Legal Protection Of Indigenous Forests In Realizing Indigenous Legal Community Rights In Jambi Province", Library Philosophy and Practice (e-journal), 2019. https://digitalcommons.unl.edu/cgi/viewcontent.cgi?article=6470\&context=libphilprac 
minyak ilegal (illegal drilling) memiliki kendala. Hal ini didasari bahwa begitu banyaknya kasus penambangan minyak ilegal (illegal drilling) yang masuk ke Polres Batanghari sedangkan personil unit Tipiter masih kurang. Kuncoro mengemukakan:

Dalam melakukan penyidikan kita terkendala pada minimnya personel yang kita miliki dimana untuk unit yang menangani kasus tindak pidana minerba kita memilik unit khusus yaitu tipiter yang mana jumlah anggotanya yaitu sebanyak 4 orang dengan rincian 1 orang kanit dan 3 orang penyidik, sehingga dengan jumlah personel yang ada kita masih kewalahan dalam melakukan proses penyidikan. Selain itu kita tidak dibantu oleh Penyidik Pegawai Negeri Sipil (PPNS) dari instansi terkait.20

Terkait dengan dukungan personel Penyidik PPNS, dikatakan oleh Novaizal Varia Utama yang mengemukakan:

Sampai saat ini kita belum memiliki Penyidik Pegawai Negeri Sipil (PPNS) sebagaimana yang telah diamanatkan oleh Undang-Undang Nomor 22 Tahun 2001 tentang Minyak dan Gas Bumi sehingga untuk penanganan perkara penambangan emas ilegal tersebut langsung ditangani oleh pihak penyidik dari kepolisian. Memang untuk PPNS itu sendiri kita juga telah merencanakan untuk membentuk PPNS namun saat ini hal tersebut belum terealisasi. Ke depan kita berharap agar Dinas ESDM untuk dapat segera merekrut PPNS dan melakukan penyidikan terhadap tindak pidana pertambangan tersebut. ${ }^{21}$

Oleh Kuncoro yang mengatakan:

Dari segi sarana dan prasarana kita mengalami kendala yaitu:22

1. Dalam melakukan penindakan terhadap pelaku tindak di lapangan kita terkendala akan medan yang ditempuh dimana kegiatan penambangan minyak ilegal (illegal drilling) tersebut dilakukan di dalam hutan dan juga di sungai, jika di sungai kita belum memiliki perahu karet sehingga kita di dalam melakukan penangkapan tidak optimal dan menyebabkan kaburnya para penambang.

2. Anggaran kita terbatas sehingga kurang maksimalnya upaya penindakan yang kita lakukan.

3. Untuk mengetahui apakah lingkungan tersebut tercemar atau tidak maka harus dilakukan pengujian di laboraturim namun kita terkendala akan alat yang digunakan untuk menguji hal tersebut jadi jika kita ingin menguji hal tersebut kita harus mengirim sampel ke Jambi.

Dalam penegakan Hukum penambangan illegal ini terdapat kendala yang paling besar yaitu berada pada penegak hukumnya itu sendiri, karena apabila substansi hukumnya sudah ada dan dengan jelas di jelaskan tentang apa saja yang boleh dan tidak boleh di lakukan, di lapangan tidak jarang ditemukan bahwa kendala terbesar berada pada penegak hukum yang melanngar hukum itu sendiri dengan menjadi pemilik alat-alat penambangan itu sendiri dan menjadi orang-orang yang mem back-up kegiatan penambangan tersebut, tidak jarang bahwa figur penegak hukum yang harusnya menegakkan malah melindungi kegiatan tersebut.

Kendala yang dihadapi dalam penegakan hukum terhadap tindak pidana

20 Wawancara dengan Kuncoro, Penyidik Tipiter, Polres Batanghari, tanggal 24 Januari 2020.

21 Wawancara dengan Novaizal Varia Utama, Kepala Seksi Pengawasan Dinas Energi dan Sumber Daya Mineral (ESDM) Provinsi Jambi, Tanggal 22 Januari 2020.

22 Wawancara dengan Kuncoro, Penyidik Tipiter, Polres Batanghari, tanggal 24 Januari 2020. 
penambangan minyak ilegal (illegal drilling) di Kabupaten Batanghari adalah berupa

1. Kurangnya Peralatan

Peralatan yang dimaksud yaitu sarana transportasi, alat-alat untuk kepentingan penyidikan seperti media yang bisa menampilkan potret diri pelaku secara cepat. Kekurangan peralatan ini dapat menyebabkan kendala dalam penegakan hukum terhadap tindak pidana penambangan minyak ilegal (illegal drilling) di Kabupaten Batanghari, karena banyak kasus penambangan minyak ilegal (illegal drilling) yang tidak terlacak dan pelakunya tidak tertangkap.

2. Kurangnya Personil

Personil yang ada di Polres Batanghari masih sangat sedikit dibandingkan dengan luas wilayah dan berbagai macam tindak pidana yang terjadi di wilayah hukum Polres Batanghari, sehingga masing-masing personil (penyidik) bertanggung jawab dengan tugasnya masing-masing. Apabila terjadi suatu kasus penambangan minyak ilegal (illegal drilling), tidak ada personil yang menangani hal tersebut di kantor, maka harus menunggu personil tersebut untuk mengambil tindakan pengejaran. Dengan keadaan ini sudah barang tentu pelaku telah jauh melarikan diri yang sulit dikejar dalam waktu yang singkat, apalagi tidak ada keperdulian warga masyarakat akan tindak pidana penambangan minyak ilegal (illegal drilling) tersebut.

Segi sarana dan prasarana guna mendukung untuk melakukan penegakan hukum terhadap tindak pidana penambangan minyak ilegal (illegal drilling) masih terdapat kendala. Dalam hal ini kelemahan terkait dengan jumlah personil anggota sehingga bisa menghambat proses penegakan hukum tindak pidana penambangan minyak ilegal (illegal drilling). Hal ini didasari pula bahwa jumlah perkara tindak pidana penambangan minyak ilegal (illegal drilling) yang terjadi di Kabupaten Batanghari yang sering terjadi dengan bertambahnya masyarakat yang melakukan penambangan minyak ilegal (illegal drilling) dengan tidak memperhatikan kelestarian lingkungan. Selain itu juga, terkait sarana dan prasarana yang dibutuhkan guna mendukung pelaksanaan tugas yaitu perahu karet guna memudahkan aparat dalam melakukan penindakan terhadap pelaku penambangan minyak ilegal (illegal drilling) yang berada di lokasi yang hanya bisa diakses menggunakan perahu karet.

Tanpa adanya sarana atau fasilitas yang memadai maka tidak mungkin penegakan hukum yang dilakukan akan lancar. Sarana dan fasilitas tersebut mencakup tenaga manusia yang berpendidikan dan terampil, organisasi yang baik, peralatan yang memadai, keuangan yang cukup dan seterusnya. Kalau hal ini tidak terpenuhi, maka penegakan hukum yang dilakukan tidak dapat mencapai tujuan yang akan dicapai.

Terdapat beberapa faktor yang membuat sulitnya penegakan dalam Illegal Drilling tersebut, sebagai berikut:

1. Faktor Kesadaran Hukum Masyarakat

Faktor masyarakat ini merupakan hal yang sangat urgent dalam penegakan hukum. Dalam hal tindak pidana penambangan minyak ilegal (illegal drilling), data di lapangan menunjukkan bahwa kesadaran hukum masyarakat masih tergolong rendah. Hal ini didasari bahwa dari data pelaku penambangan minyak ilegal (illegal drilling), sebagaimana yang dikatakan oleh Siswanto, yaitu:

Kesadaran masyarakat masih rendah ini terlihat dari masih banyaknya terjadi pembiaran dan juga sikap acuh tak acuh masyarakat kepada aktivitas 
penambangan minyak ilegal (illegal drilling), padahal mereka tahu bahwa hal tersebut dapat mengancam kelestarian lingkungan. ${ }^{23}$

Ketika kita lakukan penertiban mereka cenderung untuk melakukan perlawanan terhadap aparat di lapangan sehingga kita kesulitan dalam mengambil tindakan, dan juga mereka tidak jarang bentrok dengan aparat.

2. Faktor Luas Wilayah

Kabupaten Batanghari memiliki 8 Kecamatan dan 14 Kelurahan yang luas wilayahnya 5.804,00 km persegi dan sebaran penduduk 53 jiwa perkilometer. Dengan luas wilayah yang begitu luas dan banyaknya titik penambangan yang berlokasi berjauhan membuat sulitnya penegakan hukum mengenai illegal drilling tersebut, ditambah dengan sedikitnya jumlah personil TIPITER (tindak pidana tertentu) menjadikan salah satu faktor yang menyebabkan sulitnya penegakan hukum Illegal Drilling di Kabupatan Batanghari.

3. Faktor Aparat

Berdasarkan Hasil wawancara terhadap beberapa responden, dapat di ketahui bahwa salah satu faktor kendala sulitnya menegakkan hukum menegenai illegal drilling tersebut adalah dikarenakan oknum-oknum aparat yang saling bekerjasama dengan para pelaku tindak pidana illegal drilling yang selalu mem back up kegiatan tersebut, sehingga kegiatan tindak pidana illegal drilling tersebut sulit untuk ditegakkan berdasarkan Hukum dan Undang-Undang yang berlaku.

\section{SIMPULAN}

Pengaturan mengenai kegiatan Illegal Drilling di Kabupaten Batanghari diatur dalam Undang-Undang No. 22 tahun 2001 Tentang Minyak dan Gas Bumi pada Pasal 52 dan diperkuat dalam Pasal 53 dan pasal-pasal lainnya di dalam Undang-Undang tersebut yaitu: Faktor penyebab terjadinya Illegal drilling karena tertutupnya akses masyarakat atas wilayah alam disekitar mereka. Sedangkan kendala-kendala dalam tindak pidana penambangan minyak ilegal (illegal drilling) di Kabupaten Batanghari, hal ini disebabkan oleh: Kurangnya kesadaran hukum warga masyarakat, terhadap perbuatan penambangan minyak ilegal (illegal drilling). Sulitnya untuk membuktikan tindak pidana karena kurang barang bukti atau tidak ada barang bukti. Jumlah aparat penyidik tidak sesuai dengan jumlah kasus yang terjadi di wilayah hukum Kabupaten Batanghari.

23 Wawancara dengan Siswanto, Kanit Tipiter, Polres Batanghari, tanggal 22 Januari 2020. 


\section{DAFTAR PUSTAKA}

\section{Dokumen Hukum}

Republik Indonesia, Undang-Undang Dasar 1945.

Undang-Undang Tentang Minyak dan Gas Bumi. UU Nomor 22 Tahun 2001. LNRI Tahun 2001 Nomor 136, TLNRI Nomor 4152.

Undang-Undang Tentang Pertambangan Mineral dan Batubara. UU Nomor 4 Tahun 2009. LNRI Tahun 2009 Nomor 4, TLNRI Nomor 4959.

Peraturan Menteri Energi dan Sumber Daya Mineral Tentang Pedoman Pengusahaan Pertambangan Minyak Bumi Pada Sumur Tua. Nomor 01 Tahun 2008.

\section{Buku}

Ali, Achmad. Menguak Teori Hukum (Legal Theory) dan Teori Peradilan (Judicialprudence) Termasuk Undang-Undang (Legalprudence). Jakarta: Kencana Prenada Media Group, 2009.

H.S, Salim. Hukum Pertambangan di Indonesia. Jakarta: PT Raja Grafindo Persada, 2005.

Ibrahim, Johnny. Teori dan Metodologi Penelitian Hukum Normatif. Malang: Bayu Media Publishing, 2006.

Marzuki, Peter Mahmud, Penelitian Hukum. Jakarta: Kencana, 2008.

Mertokusumo, Sudikno. Mengenal Hukum (Suatu Pengantar). Yogyakarta: Liberty, 1999.

Nasution, Bahder Johan. Metode Penelitian Ilmu Hukum. Bandung: Mandar Maju, 2008.

Nurbani, Erlies Septiana dan Salim H.S. Penerapan Teori Hukum pada Tesis dan Skripsi. Jakarta: PT Raja Grafindo Persada, 2013.

Riswandi, Budi Agus. Aspek Hukum Internet Banking. Jakarta: Raja Grafindo Persada, 2005.

Soekanto, Soerjono. Faktor-Faktor Yang Mempengaruhi Penegakan Hukum. Jakarta: PT Raja Grafindo Persada, 1983.

Sudarsono. Kamus Hukum. Jakarta: Rineka Cipta, 1992.

Sunarso, Siswanto. Hukum Pidana Lingkungan Hidup dan Strategi Penyelesaian Sengketa. Jakarta: Rineka Cipta, 2005.

Tim Penyusun. Kamus Besar Bahasa Indonesia Edisi Ke-Empat, Jakarta: Depdiknas, 2008.

Waluyo, Bambang. Pidana dan Pemidanaan. Jakarta: Sinar Grafika, 2008. 
Wantu, Fence M. Kepastian Hukum Keadilan dan Kemanfaatan. Yogyakarta: Pustaka Pelajar, 2011.

\section{Jurnal}

C, Anwar, "Problematika Mewujudkan Keadilan Substantif Dalam Penegakkan Hukum di Indonesia", Jurnal Publikasi FH Universitas Widyagama Malang, Vol. 3, No.1, (2010).

http://publishing-widyagama.ac.id/ejournal-v2/index.php/jk/article/view/ $311 / 306$

Candra, Adi, "Pemanfaatan Sumur Minyak Tua Sisa Eksploitasi Peninggalan Belanda Dalam Hubungannya Dengan Perekonomian Masyarakat di Kabupaten Musi Banyuasin", Jurnal Muamalah, Vol. 3, No. 1, (2017).

http://jurnal.radenfatah.ac.id

Hafrida, et.al, "Penyuluhan Hukum Resolusi Konflik Sumber Daya Alam Di Kabupaten Batanghari”, Jurnal Pengabdian pada Masyarakat, Vol. 29, No. 4, (2014). http://www.resercgate.net/publication/328277838_penyuluhan_hukum_res olusi_konflik_sumber_daya_alam_di_kabupaten_batanghari

Helmi, et.al, "Documenting Legal Protection Of Indigenous Forests In Realizing Indigenous Legal Community Rights In Jambi Province", Library Philosophy and Practice (e-journal), (2019).

https://digitalcommons.unl.edu/cgi/viewcontent.cgi?article=6470\&context=l ibphilprac

Helmi, et.al, "Legal Protection To Manage Forest Resources Based On Local Wisdom", Journal of Critical Reviews, Vol. 7, No. 9, (2020). http://www.jcreview.com/?mno=112244

Kelly, Danial, "Natural Resources Law in Australia: Principals and Practices, Jambe Law Journal”, Vol. 1, No. 2, (2018). http://jlj.unja.ac.id

Lioty, Riyandani Rahmadiah, "Penanganan Illegal Tapping, Illegal Drilling dan Penyelewengan Bahan Bakar Minyak (BBM) Bersubsidi di Indonesia Tahun 2011-2015", Journal of International Relations, Vol. 3, No. 4, (2017). http://ejournal-s1.undip.ac.id/index.php/jihi

\section{Website}

https://mediarealitas.com , diakses 04 Desember 2019. 